\title{
Krigen i Ukraine tøer frosne konflikter op
}

\section{Af Vibeke Sperling}

Moskva har holdt fastfrosne konflikter systematisk ved lige. For Vesten har de længe - om end noget overset - været varsler om store kriser som nu i Ukraine.

"For en fremtid sammen med Rusland", står der på busser i Tiraspol, hovedbyen $\mathrm{i}$ løsrivelsesregionen Transnistrien i Moldova. Og en annonce viser en lokal familie med Kreml som den beskyttende fæstning i baggrunden.

Transnistrien er en af de såkaldt frosne konflikter i det postsovjetiske rum. Området har under russisk beskyttelse de facto været selvstændigt siden en løsrivelseskrig i begyndelsen af 1990'erne. Men det var først Ruslands annektering af Krim i marts 2014, der rettede Vestens større opmærksomhed mod den og andre fastfrosne konflikter som Abkhasien og Sydossetien i Georgien.

Selv om Moskva har holdt disse konflikter ved lige, har det vist en vis tilbageholdenhed under Ukraine-krisen. Separatisterne i de tre områder ønsker større tilknytning til eller indlemmelse i Rusland, men foreløbig venter Kreml og ser, mens russiske såkaldt fredsbevarende styrker holder dem under opsyn. Det anslås, at Ruslands 14. arme, der er omdøbt til Russiske Styrkers Operationsenhed (OGRF), tæller mindst 2.000 mand. Kreml hævder, at OGRF er nødvendigt for at beskytte de store våbenlagre i området, der stammer fra den kolde krig.

Transnistriens beliggenhed gør det særlig vigtigt for Ruslands bestræbelser for at bremse EU's og NATOs udvidelse mod øst, som Transnistrien holder Moldova effektivt væk fra. Og området har også særlig betydning for Moskva som muligt medlem af det Nye Rusland, Novorossija, som de prorussiske separatister i det østlige Ukraine kæmper for.

\section{Samme strategi}

Kreml synes at have samme strategi for Transnistrien som for det østlige Ukraine, hvor de såkaldte 'folkerepublikker', Donetsk og Luhansk, udråbte sig som selvstændige i april 2014 på samme måde som Transnistrien i 1990. Kreml ønsker næppe de pågældende områder direkte integreret i Rusland, men ønsker dem som russiske fødder i døren til Moldovas og Ukraines integration vestover.

Hvad strategien er kan blandt andet læses i et såkaldt Kosak memorandum fra 2003, ifølge hvilket Transnistrien skulle have de facto vetoret over Moldovas vigtigste beslutninger, da Transnistrien og en anden prorussisk region, Gagausien, skulle udpege halvdelen af det moldoviske senats 26 senatorer.

Vibeke Sperling er tidligere udenrigskorrespondent for Politiken. Hun er nu tilknyttet Dagbladet Information. 


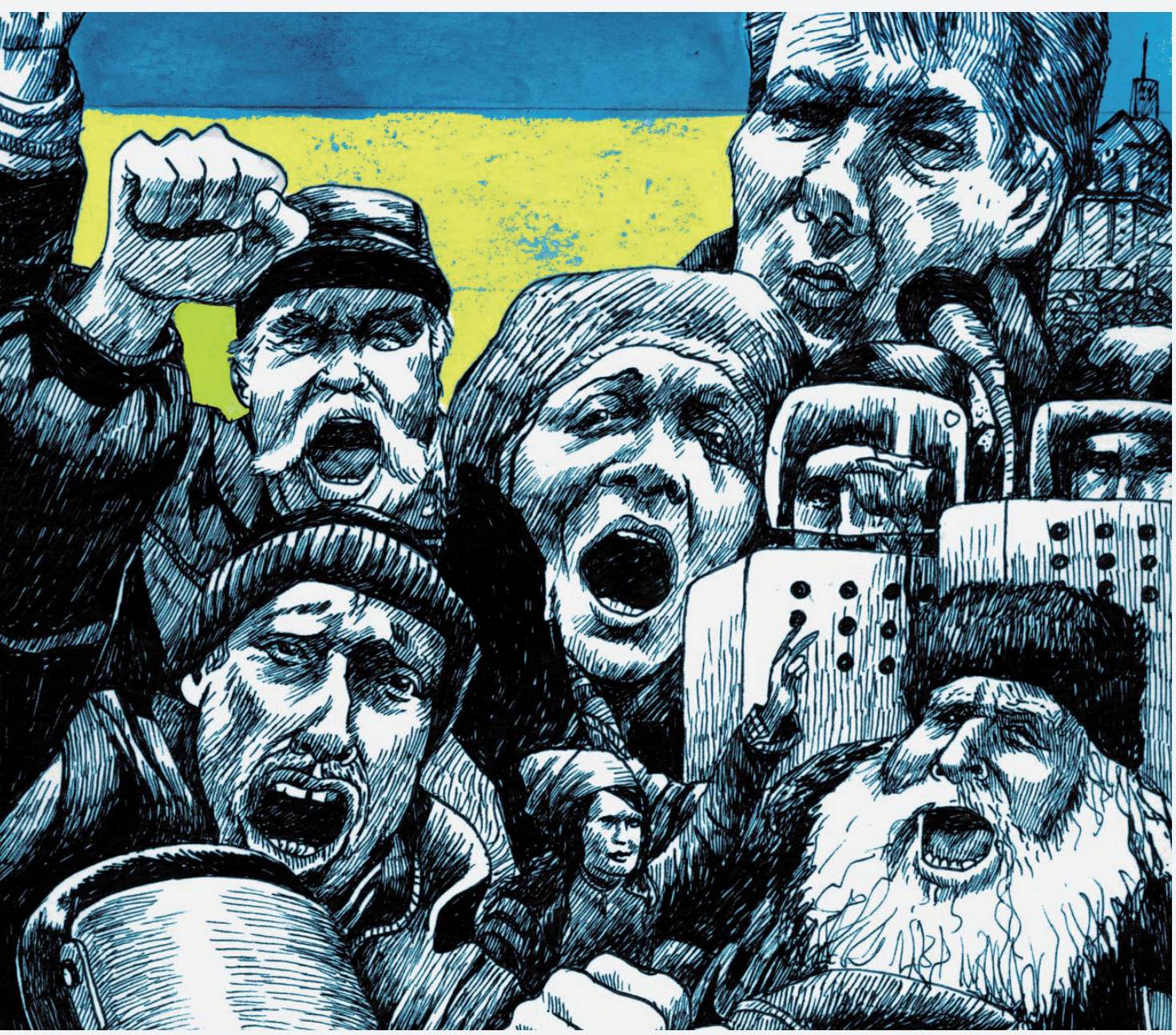

ILLUSTRATION: Project syndicate, 2015

Det memorandum skulle også legalisere de russiske troppers tilstedeværelse i landet.

Moldova skulle føderaliseres, primært for at holde det i Ruslands interessesfære. Ruslands ønske om at gennemføre samme strategi i Ukraine blev fremlagt i marts 2014, da udenrigsminister Sergej Lavrov bad "USA og dets europæiske partnere om at acceptere vores forslag om, at etniske russiske regioner i det østlige og sydlige Ukraine gives omfattende autonom magt, uafhængigt af Kijev".
Der er dog en række forskelle mellem Transnistrien og Ukraines Donbas-region, der har ti gange så mange indbyggere og fælles grænse med Rusland. Ruslands økonomiske og militære støtte til separatisterne er og vil fremover derfor være langt større til Donbas end til Transnistrien.

De fastfrosne konflikter blev skabt efter Sovjetunionens sammenbrud af eksplosioner af etniske og territoriale konflikter, der var holdt nede af sovjetmagten.

Deres historie går imidlertid tilbage til Stalins grænsedragninger imellem sov- 
jetrepublikkerne, som bevidst delte etniske grupper ifølge Stalins del-og-hersk strategi.

Da Sovjetunionen blev nedlagt og efterfulgt af Sammenslutningen af Uafhængige Stater (SNG) i 1991 forblev disse konflikter uløste.

Fastfrosne konflikter er en situation, hvor aktiv væbnet konflikt er bragt til ende, uden at der er skabt varig fred og uden en løsning, der tilfredsstiller de stridende parter. Den blodige konflikt i de separatistkontrollerede områder i regionerne Donetsk og Luhansk i Ukraine kan således ikke defineres som fastfrossen. Men Krim er kommet med som en ny fastfrossen konflikt, for selv om det ikke er plaget af væbnet konflikt, er der ikke fundet nogen løsning, da Ukraine og det meste af det internationale samfund fastholder, at halvøen er ukrainsk.

\section{Georgien som tidlig varsel}

Den tidligere alvorligste advarsel om Kremls intentioner var de russiske styrkers indmarch i Georgien i august 2008. (Ja, krigen i Ukraine har taget mange flere liv, men dér er der tale om en potentiel fremtidig fastfrossen konflikt). Russiske styrker rykkede ind i Sydossetien, angiveligt for at beskytte denne løsrivelsesregion imod Georgiens forsøg på at genetablere kontrol med området. Russiske styrker var imidlertid også rykket ind i Abkhasien, den anden georgiske løsrivelsesregion, uden nogen lignende anledning.

Da jeg dækkede konflikten i Georgien for dagbladet Politiken, oplevede vi en dramatisk dag, hvor russiske kampvogne rullede mod hovedstaden Tbilisi. Russiske soldater, der vinkede ned til os fra kampvognene, råbte: “Til Tbilisi. Til Tbilisi". En georgisk taxachauffør fortalte, at en russisk soldat havde trykket hans hånd og med henvisning til landets daværende præsident Mikhail Saakasjvili sagt: “Kør hjem til Tbilisi og fortæl Saakasjvili, at der først bliver fred, når han går af."

Russerne angreb ikke Tbilisi. Den fremrykkende kampvognskolonne drejede fra $i$ retning af en tidligere georgisk militærforlægning mindre end $30 \mathrm{~km}$ fra hovedstaden. På en pressekonference hævdede Saakasjvili, at invasionen var resultat af, at NATO på sit topmøde i Bukarest i april samme år ikke havde givet Georgien og Ukraine en såkaldt aktionsplan for medlemskab af alliancen (MAP).

"Det tolkede Moskva som grønt lys til at angribe os," sagde han, som dengang var Vestens håb og hovedpine - det sidste, fordi han var så kompromisløs over for Moskva. Saakasjvilis overmod i opgøret med Putin, hvor der også var tale om et indædt gensidigt had, var affødt af den overbevisning, at Vesten ville komme Georgien til undsætning - næsten lige meget, hvor meget han udfordrede Kreml. Fra Washington udtalte præsident George W. Bush da også, at USA "aldrig ville lade Georgien i stikken”. Men det gjorde USA - og EU - i praksis.

Allerede dengang stod det klart - selv om vestlige politikere og militærfolk nedtonede den mulighed - at et russisk angreb på Ukraine efter al sandsynlighed ville blive det næste. Den ukrainske sikkerhedsekspert Alina Pastukhova sagde, at Ukraine ville klare sig bedre end Georgien: "Men resultatet bliver næsten det samme med nederlag for Ukraine," sagde hun, for "Ukraine har fem gange så mange styrker som Georgien, men intet i sammenligning med Rusland".

Tusindvis demonstrerede samtidig i Sevastopol på Krim imod Ukraines forsøg på at hjælpe Georgien. Ukraines daværende præsident, Viktor Jusjtjenko, intensiverede sine forsøg på at få ukrainerne til at støtte NATO-medlemskab, som der var 
Saakasjvilis overmod i opgøret med Putin, hvor der også var tale om et indædt gensidigt had, var affødt af den overbevisning, at Vesten ville komme Georgien til undsætning - næsten lige meget, hvor meget han udfordrede Kreml.

flertal for i det vestlige og i dele af det centrale Ukraine, men ikke blandt flertallet af de otte millioner russere i landets østlige dele og på Krim. "Ukraine er også truet på sine grænser, og således er vi på randen af en alvorlig militærkonflikt," sagde Jusitjenko - flere år før det skete.

Sovjetunionens sidste præsident Mikhail Gorbatjov udtalte, at Georgien bar hele skylden for den russiske invasion. Hertil sagde den tidligere sovjetiske udenrigsminister og georgiske præsident, Eduard Sjevardnadse, mens de russiske kampvogne rullede i landet: "Min ven Gorbatjov siger det skinbarlige idioti. Nogen har pålagt ham det, og Rusland vil bombe Georgien tilbage til underdanighed." Det lykkedes ikke, men Georgiens vej mod vest er effektivt bremset af de fastfrosne konflikter på landets territorium.

Sjevardnadse var overbevist om, at også andre områder var i oplagt fare, nu hvor Rusland havde vist, at det ikke standsede ved egne grænser. "Men USA er medskyldig. Jeg er en gammel ven af USA, men det begår store fejl."

Det var ifølge Sjevardnadse eksempelvis meget umodent ikke at være bevidst om, at Rusland ville reagere hårdt på USA's planer om missilskjold og på NATOs udvidelse østover.

"Ukraine er det mest udsatte land efter Georgien". Sjevardnadse mente som Saakasjvili, at hvis NATO havde givet Georgien (og Ukraine) en handlingsplan for medlemskab, ville russerne ikke være rykket ind i Georgien.

Om Sydossetiens og Abkhasiens mulige tilbagevenden til Georgien sagde
Sjevardnadse: "Det er georgisk land, og almindelige indbyggere kan overbevises $\mathrm{om}$, at de kan få et meget bedre liv som selvstyrede dele af Georgien. Men de separatistiske regimer ønsker ikke den løsning, for de tjener formuer på at følge Moskva og på smugling af våben og alt andet igennem Sydossetien og Abkhasien."

Sjevardnadse, der døde 7. juli 2014, forstod Rusland klarere end de fleste, og han var den første leder eller tidligere leder af en sovjetrepublik, der forudså den russiske imperialismens genopsving. I juni 2007, mere end et år før den russiske invasion i Georgien, blev han citeret af nyhedssiden Civil Georgia for at skrive: "Ruslands århundredlange ekspansionsproces og indhug $i$ andre landes territorium fortsætter i dag."

Rusland suspenderede det militære samarbejde med NATO i protest imod de hårde vestlige reaktioner på invasionen $\mathrm{i}$ Georgien. Men så blev der stille om den sag, også om at Rusland i strid med troppebegrænsningsaftaler skruede op for sine styrker i Sydossetien og Abkhasien.

\section{Medvedev advarer}

Efter afslutningen på krigen i Georgien blev de to løsrivelsesregioner igen fastfrosne konflikter, og Ruslands konflikt med Vesten blev fastfrosset på et lidt højere niveau, men Vesten accepterede de facto de fastfrosne konflikter som et fait accompli. Også selv om Moskva klart sagde, at det ville gå videre med brug af en anden fastfrossen konflikt, Transnitrien, til at true Moldova med samme behandling som Georgien. 
Ruslands daværende præsident, Dmitrij Medvedev, advarede under et besøg $\mathrm{i}$ Moldova sin moldoviske kollega imod at gentage Georgiens fejl, in casu over for Transnitrien.

"Da den georgiske ledelse gik fra forstanden og søgte at generobre Sydossetien, blev alle problemer værre, og en militær konflikt brød ud. Det er en alvorlig advarsel til alle," sagde Medvedev og tilføjede: "Vi må håndtere alle andre konflikter i det lys."

Og Moskva skærpede konflikten ved at anerkende Sydossetien og Abkhasien som selvstændige lande. Det var en klar udfordring til EU og USA, der krævede en forhandlingsløsning for de to georgiske provinser, som med russisk politisk, militær og økonomisk støtte de facto har været selvstændige siden løsrivelseskrige i begyndelsen af 1990'erne.

Da jeg dengang talte med sikkerhedsanalytikeren Maria Lipman ved Carnegie Centret i Moskva, sagde hun: "Kreml spiller på, at Vesten ikke kan gøre noget som helst, hvilket EU, USA og NATO klart har demonstreret. Anerkendelse af de georgiske løsrivelsesregioner kan kun yderligere skærpe konflikten med Vesten, men Kreml er helt ligeglad og føler nu, at det er på den grønne gren."

Meget af fortællingen i 2008 blev dækkende for Ukraine i 2014.

\section{Rusland glemmer ikke}

I 2008 opsøgte jeg Estlands præsident Toomas Hendrik Ilves, der mente, at EU og NATO burde bekymre sig langt mere om Georgien og de andre fastfrosne konfliktområder i det postsovjetiske rum. Ilves sagde også det, som Vesten først konkluderede efter Ruslands annektering af Krim:

"Hele paradigmet for sikkerhedspolitikken er ændret fra den hidtil gældende orden. Logikken var efter Sovjetunionens sammenbrud i 1991, at Rusland stort set kunne gøre, hvad det ville, så længe det respekterede Slutakten fra Helsinki om respekt for Europas grænser. Men det holder ikke efter invasionen i Georgien. Vi er nu tilbage til NATOs oprindelige kerneopgave: Europas forsvar."

På spørgsmålet, om invasionen i Georgien ikke burde være et wake up call for EU og NATO, svarede Ilves: “Jo, men de er ikke stået ud af sengen. De har i stedet trykket på slumreknappen”. Det var ifølge Ilves en faretruende historieløshed i EU-kredse, der "håbede på, at hele bare bliver overstået, så det kan blive business as usual."

Til spørgsmålet om Baltikum allerede dengang kunne komme i skudlinjen af russiske forsøg på at skabe fastfrosne konflikter med russiske mindretal i de baltiske lande, sagde Toomas Hendrik Ilves: "Jeg vil være henrykt, hvis russerne bare ville glemme os, så vi kan glemme dem."

Men Kreml glemmer ikke konflikterne efter Sovjetunionens sammenbrud i lande uden for Ruslands grænser. Det glemmer heller ikke det armensk befolkede Nagorno-Karabakh, der i Stalintiden blev lagt under sovjetrepublikken Aserbajdsjan.

I kølvandet på eskaleringen af konflikten i Ukraine satte opvarmning ind i og omkring de fastfrosne konflikter, og de nåede varmegrader, så vi måske ikke længere kan tale om dem som fastfrosne.

Dagen efter folkeafstemningen på Krim 16. marts 2014 blev der holdt folkefest i Karabakhs hovedby, Stepanakert, hvor indbyggerne tolkede begivenhederne på Krim som en styrkelse af deres krav om international anerkendelse af deres selvproklamerede selvstændighed.

Der kan dog næppe drages parallel imellem Krim og Karabakh. Armeniernes tilkæmpede frihed for Karabakh fremstod 
“Desværre viser nye væbnede sammenstød i regionen, at Nagorno-Karabakhkonflikten ikke længere er fastfrosset. Man kan ikke sige til en såret eller død soldats familie, at det er en fastfrosset konflikt."

som en del mere legitim end Krims vej tilbage til Rusland. Stepan Grigorjan, leder af et analysecenter i den armenske hovedstad Jerevan, sagde: "Det er en fornærmelse imod det armenske folk at sammenligne Krim med Karabakh."

Den nye onde cirkel i Ukraine bidrog til at genoplive volden imellem aserbajdsjanerne og armenierne med de værste militære sammenstød om Karabakh i eftersommeren og efteråret 2014, siden den skrøbelige våbenhvile blev indgået i 1994. Trods en militæralliancen mellem Rusland og Armenien har Rusland forsynet begge parter med våben - ja, i de seneste år har Aserbajdsjan fået større russiske våbenleverancer end Armenien.

James Warlick, amerikansk medformand for de internationale mæglere i Minsk-gruppen under OSCE, sagde til Vestnik Kavkaza i august 2014: "Desværre viser nye væbnede sammenstød i regionen, at Nagorno-Karabakhkonflikten ikke længere er fastfrosset. Man kan ikke sige til en såret eller død soldats familie, at det er en fastfrosset konflikt." Minsk-gruppen har siden 1994 søgt at finde en fredelig løsning. Gruppen er kollektivt ledet af USA, Rusland og Frankrig, en konstruktion, som kom til at lide under Ukraine-konflikten, hvor det blev yderst tvivlsomt, om det kollektive lederskab kunne optræde kollektivt i den nye geopolitiske situation.

Aserbajdsjans hær var under krigen om Karabakh i begyndelsen af 1990'erne i en miserabel forfatning; siden er store dele af de enorme indtægter fra landets rige energifelter brugt til oprustning og modernisering af de aserbajdsjanske styrker, og Aserbajdsjans præsident, Ilham Alijev, har gentagne gange truet med militær generobring af Karabakh.

Alijev mødtes med Armeniens præsident, Sersj Sarkisjan, i Putins sommerresidens i Sotji i eftersommeren 2014, hvor både Armenien og Aserbajdsjan sagde nej tak til Putins tilbud om russiske fredsbevarende styrker. Det eneste, der forener de to sydkaukasiske præsidenter, er skepsis over for Ruslands intentioner i deres region.

I modsætning til i de andre fastfrosne konflikter har der hidtil hverken været russiske eller internationale fredsstyrker i eller omkring Karabakh. Med mødet i Sotji ville Putin bruge genopsvinget for volden om Karabakh til fremstå som fredsmægler. Det var stærkt bekymrende for aserbajdsjanere at se Rusland overtage Krim. Det så de som en parallel til den armenske overtagelse af Karabakh.

Rusland har ikke vist særlig interesse for en endelig løsning af Karabakh-konflikten, men er heller ikke interesseret i en ny åben krig om området. Også i den konflikt viser Rusland mest interesseret i at bevare status quo. En leder i det russiske dagblad Nesavisimaja Gaseta afspejlede formentlig Kremls opfattelse: "En endelig løsning på denne sag kan vare i det uendelige, men det er ingen katastrofe. Historien er fyldt med konflikter, som ikke blev løst i løbet i årtier eller århundreder. Karabakh-konflikten er relativt ung. Den er 'kun' 20 år gammel”.

I modsætning til situationen i Sydossetien og Abkhasien blev Karabakh i mange år set som noget nær en succeshistorie, 
ikke mindst fordi Karabakh-konflikten ikke gav anledning til kappestrid mellem Moskva og Washington. Med Rusland og Vestenpå hver sin side i det geopolitiske spil om Ukraine og hele Eurasien blev de frosne konflikter både gidsler $\mathrm{i}$ og sat $\mathrm{i}$ bevægelse af det store spil om Ukraine. Moskva ser en omend skrøbelig status quo som den bedste måde at holde Sydkaukasus under kontrol på, for så længe konflikten er uløst, vil Armenien ikke smide den russiske militærbase ud landet, og så længe kan Rusland holde Armenien væk fra EU og NATO.

Moskva kan måske bidrage til at holde Aserbajdsjan tilbage fra at søge en militær afgørelse på Karabakh-konflikten, men har reelt ikke andre pressionsmuligheder over for det rige og selvbevidste Aserbajdsjan end at ophøre med at levere det våben. Rusland har imidlertid allerede leveret våben nok til at styrke den aserbajdsjanske hær afgørende, så krigsfaren er yderst reel.

\section{Ikke alt er Moskvas skyld}

Som tilfældet er med konflikten i det østlige Ukraine har Moskva langtfra skabt alle separatismens problemer, når det gælder de gamle fastfrosne konflikter.

I 1989 genindførte sovjetrepublikken Moldova latinsk skrift og det rumænske moldovisk som officielt sprog, og brugen af russisk blev søgt kraftigt reduceret. Det skabte stor frygt blandt landets russisktalende, der er koncentreret $\mathrm{i}$ Transnistrien, og det var en forsmag på angsten i det sydøstlige Ukraine, da de nye magthavere i Kijev afskaffede russisk som officielt sprog. Den fungerende ukrainske præsident nedlagde veto, men skaden var sket.

Skaden var også sket i Moldova, hvor Transnistrien rev sig løs i 1990, drevet af frygt for, at Moldova ville blive del af
Rumænien. Moldova var del af det rumænske Bessarabien efter Første Verdenskrig, indtil det blev besat af Sovjetunionen i 1940.

Det var Transnistrien aldrig en del af, så der eksisterer en kulturel og historisk splittelse i Moldova, som kan sammenlignes med splittelsen mellem det østlige og vestlige Ukraine. Splittelsen i Moldova pustede Putin igen til, da han i sin spørgsmål-svar runde med russerne den 17. april 2014 sagde, at Transnistrien har ret til selvbestemmelse, og at Moskva vil hjælpe med det.

Også den fastfrosne konflikt om Transnistrien blev varmet op af konflikten i Ukraine, der fik Moldovas regering til at kræve, at Moskva trækker sine styrker og våben tilbage fra løsrivelsesregionen. Transnistriens separatistiske ledelse greb anledningen til at gentage en gammel bøn til Moskva om at blive optaget i Den Russiske Føderation. Det var også affødt af den associeringsaftale, som Moldova underskrev med EU i sommeren 2014, og som skabte angst i Transnistriens ledelse for, at områdets indbyggere så ville vælge den europæiske vej.

Nye krige om de fastfrosne konflikter er næppe sandsynlige bortset fra, hvis Aserbajdsjan vælger at forsøge at afslutte konflikten om Karabakh med våben. Det vil Moldova ikke forsøge, da det ved, at Kreml i givet fald vil støtte Transnistrien. Og Moldova er sig pinagtigt bevidst, at det ikke kan regne med militær hjælp fra Vesten.

EU og NATO har imidlertid gode grunde til at vise større interesse end hidtil for Transnistrien, Abkhasien og Sydossetien, der er 'bløde' sikkerhedstrusler for Europa, da smugling af våben, narkotika og mennesker er gået og går igennem de retsløse områder.

Men argumenterne for, at Rusland kan gribe militært ind igen, er på plads, da 
hundredtusinder af Transnistriens, Sydossetiens og Abkhasiens indbyggere har russisk statsborgerskab, for der udstedes russiske pas til alle, som ønsker det.

\section{Ny fastfrossen konflikt?}

Hvis det lykkes at bremse kamphandlingerne i Ukraine - eller i det mindst holde dem nede til sporadiske kamphandlinger - kan de separatistkontrollere dele af det østlige Ukraine blive en ny fastfrossen konflikt. Hvor stor betydning, det vil få for det øvrige Ukraine, afhænger af, om det lykkes regeringen i Kijev at få det på fode.

Ruslands adfærd i det østlige Ukraine har stort set fulgt drejebogen for de gamle fastfrosne konflikter. Aserbajdsjan, Armenien, Georgien og Moldova, som har søgt at unddrage sig russisk dominans, har før Ukraine oplevet massiv direkte og indirekte støtte til separatister inden for deres grænser og er dermed blevet holdt i konstant ustabilitet siden Sovjetunionens sammenbrud.

En fastfrossen konflikt i Østukraine kan se ud til at være Putins mål, men formentlig er det snarere et Novorossija, som en russisk støttet offensiv fra februar 2015 tog sigte på at udvide ud over de separatistkontrollerede dele af regionerne Donetsk og Luhansk. Hvis det er Kremls mål, vil fastfrysning af konflikten ikke være realistisk, men flere blodsudgydelserligge forude.

Den potentielt fastfrosne konflikt i det østlige Ukraine kan få enorme politiske konsekvenser for regionen og for hele Europa, men det er et perfekt instrument for Moskva til at forhindre Kijev i de nødvendige reformer og til at destabilisere Ukraines politiske liv. Ruslands indblanding i Ukraine og i de gamle fastfrosne konflikter har således karakter af en langsigtet strategi.
Rusland kunne bruge sin indflydelse til at løse de fastfrosne konflikter, men foretrækker at forlænge dem på trods af eller måske rettere fordi - at de indebærer enorme økonomiske og sikkerhedsmæssige problemer for de ramte lande.

Alle de ovenfor nævnte konflikter peger på følgende: Enten fortsætter kampen om det postsovjetiske rum uden nogen former for regler, eller Rusland og Vesten tvinges til endelig at samarbejde om spillereglerne. Det sidste er der foreløbig ringe muligheder for under den tilspidsede øst-vest-konflikt.

Vesten har i relativt ringe omfang bekymret sig om de gamle fastfrosne konflikter, formentlig ud fra den opfattelse, at de ikke påvirkede det overordnede forhold til Rusland.

Men de har længe fortalt om Kremls strategi i det postsovjetiske område: at fastfryse konflikter for at bevare indflydelse ved at sabotere de berørte landes udvikling. En central baggrund for denne russiske strategi er visheden om, at de konfliktfyldte lande ikke kan optages i NATO eller EU, så længe det er uafklaret, hvor deres grænser går, og de ikke har fuld kontrol med deres territorier.

\section{Ikke for sent}

I Vesten føler man formentlig, at man har nok at gøre med konflikten i Ukraine, så det ikke er tiden, hvor man skal søge at fravriste Rusland kontrol med de fastfrosne konflikter. I løsrivelsesregionerne Transnistrien, Sydossetien og Abkhasien håbede de på, at Ruslands annektering af Krim ville fremme deres sag, men det kommer sandsynligvis til at gå lige modsat.

Krim blev meget dyrere end forventet for Moskva, der derfor har skåret ned på støtten til disse løsrivelsesregioner. Det gælder for dem alle, som den russiske 
kommentator og tv-vært Julia Latynina har sagt om Abkhasien: "Moskva gjorde en region afhængig af heroin, men holdt så op med at sende forsyninger af stoffet."

Det er sent - men ikke for sent - at Vesten engagerer sig meget mere i disse konflikter, der også som lovløse områder i EU's periferi er 'bløde sikkerhedsrisici' for hele Europa. Hænderne er fulde af Ukraine, men netop udviklingen $i$ Ukraine gør det mere relevant end nogensinde at beskæftige sig med de fastfrosne konflikter. For de er centrale brikker til at forstå Ruslands intentioner med Ukraine.

000 
